\title{
Synthesis of Titania-Silica Nanocomposite for Enhanced Photodegradation of Methylene Blue and Methyl Orange Dyes under UV and Mercury Lights
}

Ruchi Nandanwar, ${ }^{1}$ Jyoti Bamne,,${ }^{2,3}$ Nitu Singh, ${ }^{3}$ Kajol Taiwade, ${ }^{3}$ Vivek Chandel, ${ }^{3}$ P. K. Sharma, ${ }^{2}$ Purnima Singh, ${ }^{1}$ Ahmad Umar ${ }^{4}, 5$ and Fozia Z. Haque ${ }^{3, *}$

\begin{abstract}
A special sol-gel method is used to successfully synthesize spherical $\mathrm{TiO}_{2} / \mathrm{SiO}_{2}$ nanoparticles from titanium tetra-isopropoxide and tetraethoxysilane precursors. The prepared samples were dried at $110{ }^{\circ} \mathrm{C}$ and calcined at $300{ }^{\circ} \mathrm{C}, 500{ }^{\circ} \mathrm{C}$, and $800{ }^{\circ} \mathrm{C}$. The formed titanium oxide is in a tetragonal structure with significant pure anatase and rutile phase. The estimated particle size of the spherical nanostructure was $\sim 18.40 \mathrm{~nm}$ through transmission electron microscopy (TEM) and showed a larger Brunauer Emmett Teller (BET) surface area of $310 \mathrm{~m}^{2} / \mathrm{gm}$ for the sample calcined at $300{ }^{\circ} \mathrm{C}$. The $\mathrm{TiO}_{2}$ cores are enclosed within $\mathrm{SiO}_{2}$ particles with an average crystallite size of 10-20 nm. In atomic force microscopy (AFM) images, the same sample displayed a well-structured and macro-pore-free morphology. Fourier transform infrared spectroscopy (FT-IR) confirmed the presence of $\mathrm{Ti}-\mathrm{O}-\mathrm{Ti}, \mathrm{Si}-\mathrm{O}-\mathrm{Si}$, and $\mathrm{Ti}-\mathrm{O}-\mathrm{Si}$ metal oxide bonds to raise the anatase structure of $\mathrm{TiO}_{2}$. The ultraviolet-visible spectroscopy (UV-Vis) of as-synthesized samples reveals the visible absorption region. Photoluminescence spectroscopy (PL) shows a decrease in emission intensity and the emission band splits into sharp peaks to signify the decrease in recombination rate. These properties predict the materials to photo-degrade organic dyes. The material's photocatalytic activity was evaluated for degradation of methylene blue and methyl orange dyes. It is found that the sample calcined at $300{ }^{\circ} \mathrm{C}$ exhibits a better photodegradation for methylene blue (MB, 80-85\%) than methyl orange (MO, 70-75\%) under mercury light within 2 hours.
\end{abstract}

Keywords: $\mathrm{TiO}_{2} / \mathrm{SiO}_{2}$ nanocomposite; photo-degradation; methylene blue (MB); methyl orange (MO).

Received: 08 November 2021; Accepted: 13 January 2021.

Article type: Research article.

\section{Introduction}

Titanium dioxide $\left(\mathrm{TiO}_{2}\right)$ has been of great interest to materials scientists and physicists due to its unique properties, and it has been widely used for a variety of technological applications such as photocatalysts,,$^{[1,2]}$ solar cells, sensors, ${ }^{[3-5]}$ and memory devices. Due to its large surface area, titanium nanopowder in

\footnotetext{
${ }^{1}$ Department of Physics, Sarojini Naidu Govt. Girls Autonomous P.G. College, Bhopal-462016, Madhya Pradesh, India.

${ }^{2}$ Department of Applied Physics, Barkatullah University Institute of Technology (BUIT), Bhopal-462003, Madhya Pradesh, India.

${ }^{3}$ Optical Nanomaterials Lab., Department of Physics, Maulana Azad

National Institute of Technology (M.A.N.I.T.), Bhopal 462003,

Madhya Pradesh, India.

${ }^{4}$ Department of Chemistry, Faculty of Science and Arts, Najran

University, Najran-11001, Kingdom of Saudi Arabia.

${ }^{5}$ Promising Centre for Sensors and Electronic Devices (PCSED),

Najran University, Najran-11001, Kingdom of Saudi Arabia.

*E-mail:foziazia@rediffmail.com ( F. Z. Haque)
}

most studies is used. Most studies in the last few decades have concentrated mainly on suspending $\mathrm{TiO}_{2}$ powder as compared to the good photocatalytic activity of thin film. ${ }^{[6]}$

The sol-gel process has many advantages, including being environmentally friendly, having a low processing temperature, better homogeneity, high purity, precise composition control, and being cost-effective. ${ }^{[4-7]} \mathrm{TiO}_{2}$ is a typical n-type semiconductor with three crystal polymorphs in nature: anatase, brookite, and rutile. Brookite is the rare phase, and rutile is a high-temperature stable phase, whereas anatase is not as thermodynamically stable as rutile. Basically, both anatase and rutile have a tetragonal crystal structure. ${ }^{[7-10]}$ The $\mathrm{SnO}_{2} / \mathrm{TiO}_{2}$ and $\mathrm{SiO}_{2} / \mathrm{TiO}_{2}$ mixed oxides have been studied with different concentration rates and preparation methods to produce a simple form of single and multi-component oxide in the crystalline or amorphous form..$^{[11,12]} \mathrm{N}$. Venkatachalam et al. synthesized several crystalline forms of nano $\mathrm{TiO}_{2}$ via the sol-gel method using titanium tetra-isopropoxide as a precursor. ${ }^{[13]}$ The simple sol-gel method was used to 
effectively synthesize crystalline $\mathrm{TiO}_{2}$ nanoparticles, which showed the regular rice-grain shape and defined nano-surface as well as large surface area and subsequently higher photocatalytic activity. ${ }^{[14]}$

The mixed oxides such as $\mathrm{ZrO}_{2} / \mathrm{TiO}_{2}, \mathrm{SnO}_{2} / \mathrm{TiO}_{2}$, and $\mathrm{SiO}_{2} / \mathrm{TiO}_{2}$ have been studied using various dose rates. Various preparation methods have been investigated, with the sol-gel process being utilized to produce crystalline or amorphous forms of single and multi-component oxides. ${ }^{[15,16]}$ Recent investigations show that $\mathrm{TiO}_{2} / \mathrm{SiO}_{2}$ composites give the best support because they integrate both the mechanical and chemical characteristics of active titania. Kimura Isao et al. claimed that a simple technique may be used to make a composite microsphere and TTIP (titanium (IV) isopropoxide) had a significant effect on the morphology of titania/silica composite microspheres produced using sol-gel in reverse suspension. ${ }^{[17]} \mathrm{SiO}_{2}$, which has strong thermal stability and carrier characteristics, is commonly employed in organic compounds to increase active sites on $\mathrm{TiO}_{2}$ particles, which improves photocatalytic activity. ${ }^{[18,19]}$ Recently, the synthesized $\mathrm{TiO}_{2} / \mathrm{SiO}_{2}$ composite nanoparticle by sol-gel method served as an important item in controlling the surface properties, to provide distinct benefits in the production of highly dispersed tetrahedral coordinated materials. ${ }^{[20]}$ The photocatalytic activity of $\mathrm{TiO}_{2}$ can be improved by the addition of $\mathrm{SiO}_{2}$, which increases the surface area and surface acidity and enhances the thermal stability of the phase of $\mathrm{TiO}_{2}$ particles of the catalysts, allowing an increase in the adsorption of pollutant molecules. ${ }^{[21,22]}$

In this work, we report a simple and environment-friendly sol-gel method to synthesize $\mathrm{TiO}_{2} / \mathrm{SiO}_{2}$ nanocomposite. The characterization of the nanocomposite to determine morphologies were done by scanning electron microscopy (SEM), atomic force microscopy (AFM), and BET for surface area, X-ray diffraction (XRD) for phase identification and crystallite size. The functional group and various bonding to confirm the formation was done by Fourier-transform infrared spectroscopy (FT-IR) and transmission electron microscopy (TEM). Their optical behavior was studied by absorption spectra using UV-visible spectroscopy and emission spectra through photoluminescence spectroscopy (PL). Photocatalytic activities of these synthesized nanocomposites were studied by methylene blue (MB) and methyl orange (MO) dyes under UV and Mercury light sources.

\section{Experimental details}

\subsection{Materials}

All of the chemicals used in the study were analytical grade purity with no further purification. De-ionized water was used to make all of the solutions. Tetraethoxysilane (TEOS) $(99.9 \%$, Sigma Aldrich) was used as a $\mathrm{SiO}_{2}$ precursor and titanium tetra-isopropoxide (TTIP) (99.9\%, Sigma Aldrich) was used as a $\mathrm{TiO}_{2}$ precursor. Along with ethanol $(99.9 \%$, Merck), the catalyst was hydrochloric-acid ( $\mathrm{HCl})(99.9 \%$, Merck).

\subsection{Synthesis of the $\mathrm{TiO}_{2} / \mathrm{SiO}_{2}$ nanocomposite}

At $60{ }^{\circ} \mathrm{C}$, the synthesis was carried out with constant stirring. An electromagnetic stirring of $1100 \mathrm{rpm}$ was used to stir the mixture. 1 mole of titanium tetra-isopropoxide (TTIP) was prepared for 10 minutes with ethanol dissolving and deionized water $(35 \mathrm{ml})$ was stirred, at a $\mathrm{pH}$ of 2.5 . Then 1 mole of hydrochloric acid $(\mathrm{HCl})$ was added to the aforementioned mixture and agitated for 50 minutes. A yellowish homogeneous transparent solution was achieved at a $\mathrm{pH}$ of 1 . One mole of tetraethoxysilane (TEOS) was slowly added to the above solution, the mixture was mixed. It resulted in the formation of a white precipitate. Filtration was used to collect the precipitate, which was then washed with deionized water. Then, it was dried at $110{ }^{\circ} \mathrm{C}$ in an oven for 2 hours, the crystalline product was ground to form a fine white powder. The powder was finally split into three equal parts, one of which was calcined for one hour at $300{ }^{\circ} \mathrm{C}$, and the third at 800 ${ }^{\circ} \mathrm{C}$ to eliminate water and solvent before cooling naturally. The calcination was done in a programmed furnace. To enhance material characterization and execute a photocatalytic test, composite powder $\mathrm{TiO}_{2} / \mathrm{SiO}_{2}$ was produced. Fig. 1 depicts a schematic flowchart of the $\mathrm{TiO}_{2} / \mathrm{SiO}_{2}$ synthesized samples process using a TTIP precursor for $\mathrm{TiO}_{2}$ and a TEOS precursor for $\mathrm{SiO}_{2}$, respectively.

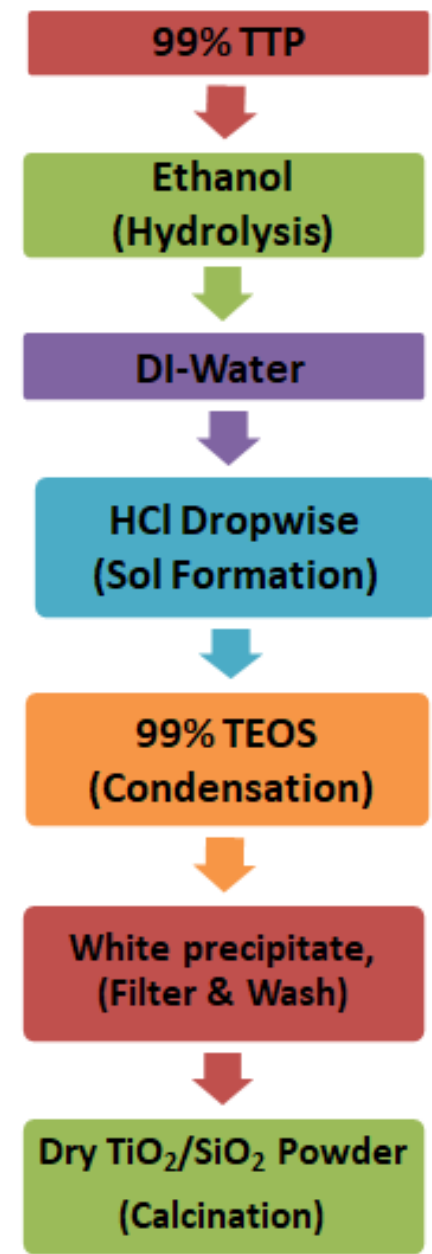

Fig. 1 A flow diagram to represent the sol-gel process for the synthesis of $\mathrm{TiO}_{2} / \mathrm{SiO}_{2}$ nanocomposites. 


\subsection{Characterizations of the synthesized $\mathrm{TiO}_{2} / \mathrm{SiO}_{2}$ nanocomposite}

The prepared $\mathrm{TiO}_{2} / \mathrm{SiO}_{2}$ nanocomposites were characterized for their optical properties using UV-visible spectroscopy recorded with an HR4000 High-Resolution Miniature Fiber Optics Spectrometer having an optical resolution as well as $0.025 \mathrm{~nm}$ (FWHM). The photoluminescence spectra were obtained using a Hitachi F-7000 fluorescence spectrophotometer. Surface morphology was studied by using SEM (JEOL-JSM-6390). The TEM micrographs were recorded using a JEM $200 \mathrm{CX}$ transmission electron microscope (JEOL, Tokyo, Japan) with a $120 \mathrm{kV}$ accelerating voltage. The NT-MDT Solver Next, Software-Nova PX was used for the samples to conduct AFM studies. The samples were placed on a clean glass plate. The Bruker D8 Advance Xray diffractometer was used to measure the X-ray diffraction patterns of samples. A sealed tube was used to generate an Xray with a wavelength of $0.154 \mathrm{~nm}(\mathrm{Cu}-\mathrm{K} \alpha)$. X-rays were detected using a rapid counting detector based on Silicon strip technology (Bruker Lynx Eye detector). These X-ray diffraction patterns were used to identify phases and estimate the size of an average crystallite. Debye Scherrer's formula was used to calculate the crystal size. The FT-IR spectra were measured using a Bruker Model-Vertex 70 Spectrometer in the spectral range of 1000 to $4000 \mathrm{~cm}^{-1}$. Quantachrome Autosorb - BET surface area analyzer was used to determine the BET surface area of prepared catalysts. To investigate the photocatalysis efficiency of all produced samples, the UV-vis absorption spectra and photoluminescence (PL) emission spectra were used.

\subsection{Photocatalytic activity of the synthesized $\mathrm{TiO}_{2} / \mathrm{SiO}_{2}$ nanocomposite}

The synthesized catalyst photocatalytic activity was characterized by experiments with ultraviolet irradiation and $\mathrm{MB}$ and MO dyes were used as a model compound for visible irradiation. To test the photocatalytic activity, a visible mercury lamp of $50 \mathrm{~W}$ and a UV Xenon lamp of $125 \mathrm{~W}$ is used. Photocatalysis experiments were performed using a selfdesigned photo-degradation reactor box and $100 \mathrm{~mL}$ glass beaker. In order to prevent light from entering the sources, the side wall beaker was covered by aluminum foil. UV and visible light sources on the rector top were fitted for uniform lighting to illuminate the sample. The distance between the lamp and the photocatalytic device was approximately $1 \mathrm{~cm}$. All the experiments were carried out in a dark room with no other light sources present. The setup used for the photodegradation experiment is shown in Fig. 2. Water based solution of $1 \times 10^{-4} \mathrm{ml} / \mathrm{L} \mathrm{MB}$ and MO was prepared. A $0.05 \mathrm{gm}$ powder catalyst suspension was added to a $100 \mathrm{~mL}$ aqueous solution of $\mathrm{MB}$ or MO. The mixture was mixed in a glass beaker and stirred for 30 minutes in dark, which allowed adsorption and even uniform dispersion using a UV or visible light source. The experiment was conducted under illuminated light at room temperature and 1-2 $\mathrm{pH}$. After 30 minutes of illumination, a $5 \mathrm{~mL}$ solution was collected and centrifuged to remove catalyst residues. This solution was then used for UVvis spectrometer analysis. After every 30 minutes of interval, a $5 \mathrm{~mL}$ solution of $664 \mathrm{~nm}$ and $332 \mathrm{~nm}$ of the corresponding maximum absorption wavelength $(\lambda$-max $)$ in MB and MO was taken from the beaker, centrifuged, and analyzed through a UV-vis spectrometer.

The concentration of remnant dye is the measure of the amount present in that solution. UV-Vis spectroscopic technique was used to determine this amount. A first-order equation describes the dye degradation in an aqueous solution as shown in Equation (1):[23]

$$
\mathrm{C}_{\mathrm{t}}=\mathrm{C}_{0} \mathrm{e}^{-\mathrm{kt}}
$$

The percentage of dye degradation was calculated by Equation (2):

$$
\text { Degradation } \%=\left[1-\frac{\mathrm{C}_{\mathrm{t}}}{\mathrm{C}_{0}}\right] \times 100
$$

where $C_{0}$ represents the dye concentrations in the solution prior to exposure and $C_{t}$ represents the dye concentrations in the solution after exposure, $t$ represents the time period of exposure, and $k$ represents the rate of degradation response. $C_{0}$ and $C_{t}$ are proportional to the intensity of the particular dye's absorption peak.

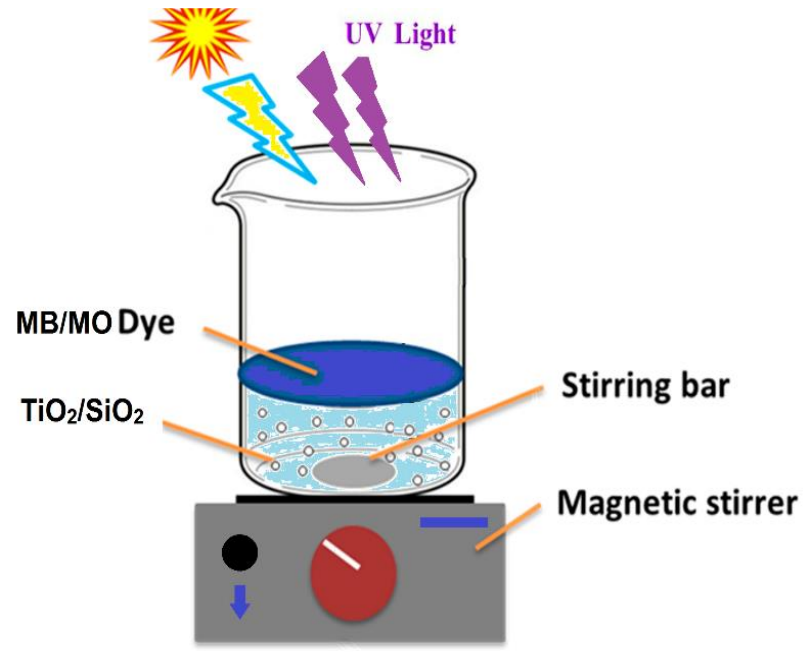

Fig. 2 Schematic of photocatalytic degradation setup.

\section{Results and discussion}

\subsection{Characterizations and properties of synthesized $\mathrm{TiO}_{2} / \mathrm{SiO}_{2}$ nanocomposites}

SEM characterization was used to study the morphology of the synthesized $\mathrm{TiO}_{2} / \mathrm{SiO}_{2}$ nanocomposites. The average particle size of the $\mathrm{TiO}_{2} / \mathrm{SiO}_{2}$ composite sample is within the nanometer range as shown by SEM images, Fig. 3. From Fig. 3(a), it is observed that the as-synthesized $\mathrm{TiO}_{2} / \mathrm{SiO}_{2}$ nanocomposite sample calcined at $300{ }^{\circ} \mathrm{C}$ temperature have spherical nanoparticles with uniformly well-defined boundaries. In calcination at $500{ }^{\circ} \mathrm{C}$, the nanoparticle is spherical in shape but boundaries are diffused as shown, in Fig. 3(b). On calcined at $800^{\circ} \mathrm{C}$, the nanoparticle consists of many uniform pores, which are aggregated as shown in Fig. 3(c). According to the SEM photographs of the prepared sample, 


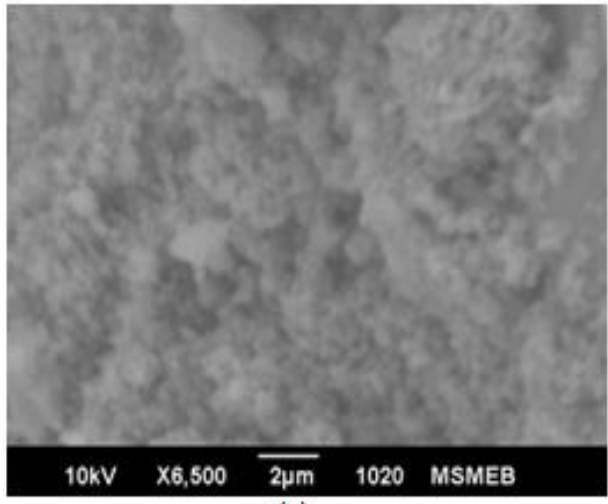

(a)

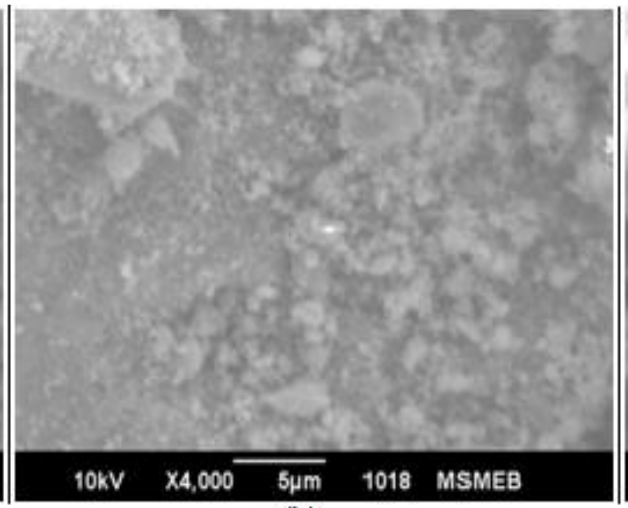

(b)

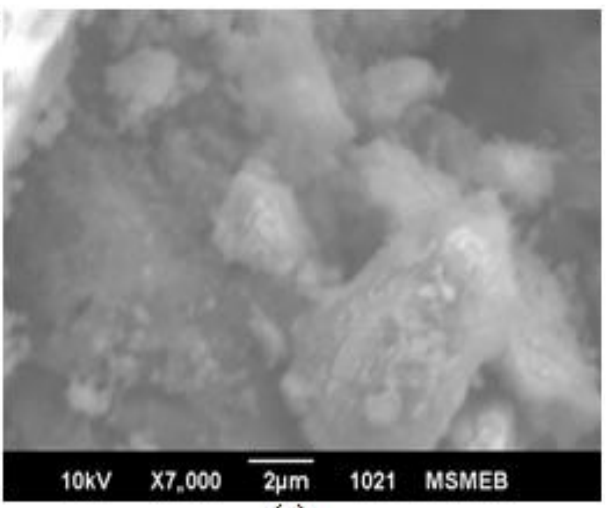

(c)

Fig. $3 \mathrm{SEM}$ micrographs of as prepared $\mathrm{TiO}_{2} / \mathrm{SiO}_{2}$ nanocomposite calcined at (a) $300{ }^{\circ} \mathrm{C}$, (b) $500{ }^{\circ} \mathrm{C}$, and (c) $800{ }^{\circ} \mathrm{C}$.

the agglomeration takes place during the crystal growth with increasing calcination temperature. In the results, it can be concluded that the samples calcined at $300{ }^{\circ} \mathrm{C}$ show welldefined boundaries with no agglomeration. This confirms the particle size by means of TEM and surface morphology by AFM. The AFM has been used to characterize the surface morphology of the prepared sample. The powder sample was mixed in acetone and then sonicate for up to $30 \mathrm{~min}$ for AFM characterization. The solution was then spin-coated on the thin glass support by Holmarc's spin coater (model no: HO-TH-05) at $6000 \mathrm{rpm}$. The structure of nanoparticles was identified through AFM-images in $5 \mu \mathrm{m} \times 5 \mu \mathrm{m}$ area.

The well-structured morphology has been displayed in AFM images of the $\mathrm{TiO}_{2} / \mathrm{SiO}_{2}$ composite, which has a macropore-free and uniform morphology calcined at $300{ }^{\circ} \mathrm{C}$ as shown in Fig. 4 (in 2D image). From Fig. 4, the 3D topography images give details about the surface roughness up to 2.169 nm. When $\mathrm{TiO}_{2} / \mathrm{SiO}_{2}$ is calcined at $300{ }^{\circ} \mathrm{C}$, the root means square roughness is thus reduced and the thin film becomes relatively smooth and has no agglomeration in the sample. In the study, the surface area was calculated using BET, total pore volume, and average pore diameter for each material. The average pore diameter is $62.49 \AA$ for synthesized $\mathrm{TiO}_{2} / \mathrm{SiO}_{2}$ samples calcined at $300{ }^{\circ} \mathrm{C}$ and the total pore volume is 0.410 $\mathrm{cc} / \mathrm{gm}$ with a specific surface area is $310 \mathrm{~m}^{2} / \mathrm{gm}$. Subsequently, the result showed that the $\mathrm{TiO}_{2} / \mathrm{SiO}_{2}$ sample calcined at $300{ }^{\circ} \mathrm{C}$ has a higher specific surface area, indicating that the material prepared in the presence of $\mathrm{SiO}_{2}$ was more thermally stable. The $\mathrm{TiO}_{2} / \mathrm{SiO}_{2}$ sample calcined at $300{ }^{\circ} \mathrm{C}$ has effectively improved the specific surface area of the solid samples, because of its high crystallinity and suppressed particle growth, and reduced pore diameter (as determined by SEM, TEM, and XRD studies) to improve the photocatalytic activity.

XRD analysis has been done to detect the $\mathrm{TiO}_{2} / \mathrm{SiO}_{2}$ nanocomposite phase composition. X-ray diffraction patterns of $\mathrm{TiO}_{2} / \mathrm{SiO}_{2}$ nanocomposite powder samples are displayed in Fig. 5. As seen below, the Scherrer equation determined the average crystallite size of the sample. Scherrer's equation is illustrated as Equation (3) ${ }^{[19]}$

$$
\mathrm{D}=\mathrm{K} \lambda / \beta \cos \theta
$$

The calculation of the crystallite size (D) from broadening of the key peak (101) anatase peak is done by Equation (3), where $\mathrm{K}$ is a constant depending on the crystallite shape (0.9), $\lambda$ is $\mathrm{X}$ ray wavelength (in this case, $\lambda=1.5418 \AA$ for $\mathrm{Cu}-\mathrm{K} \alpha$ radiation), $\beta$ is the full width at half maxima (FWHM) of the diffraction peaks and $\theta$ is the Bragg's angle, and also the unit
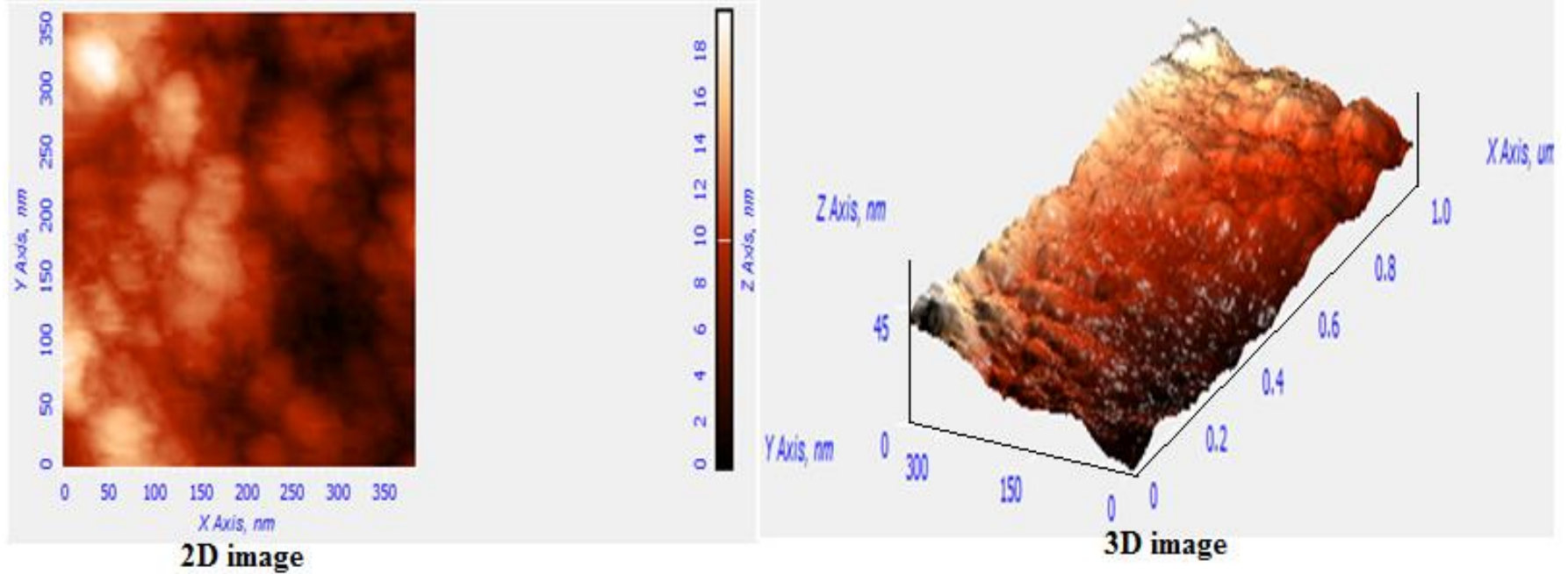

Fig. 4 The AFM images (2D and 3D surface analysis) of $\mathrm{TiO}_{2} / \mathrm{SiO}_{2}$ nanocomposite calcined at $300{ }^{\circ} \mathrm{C}$. 

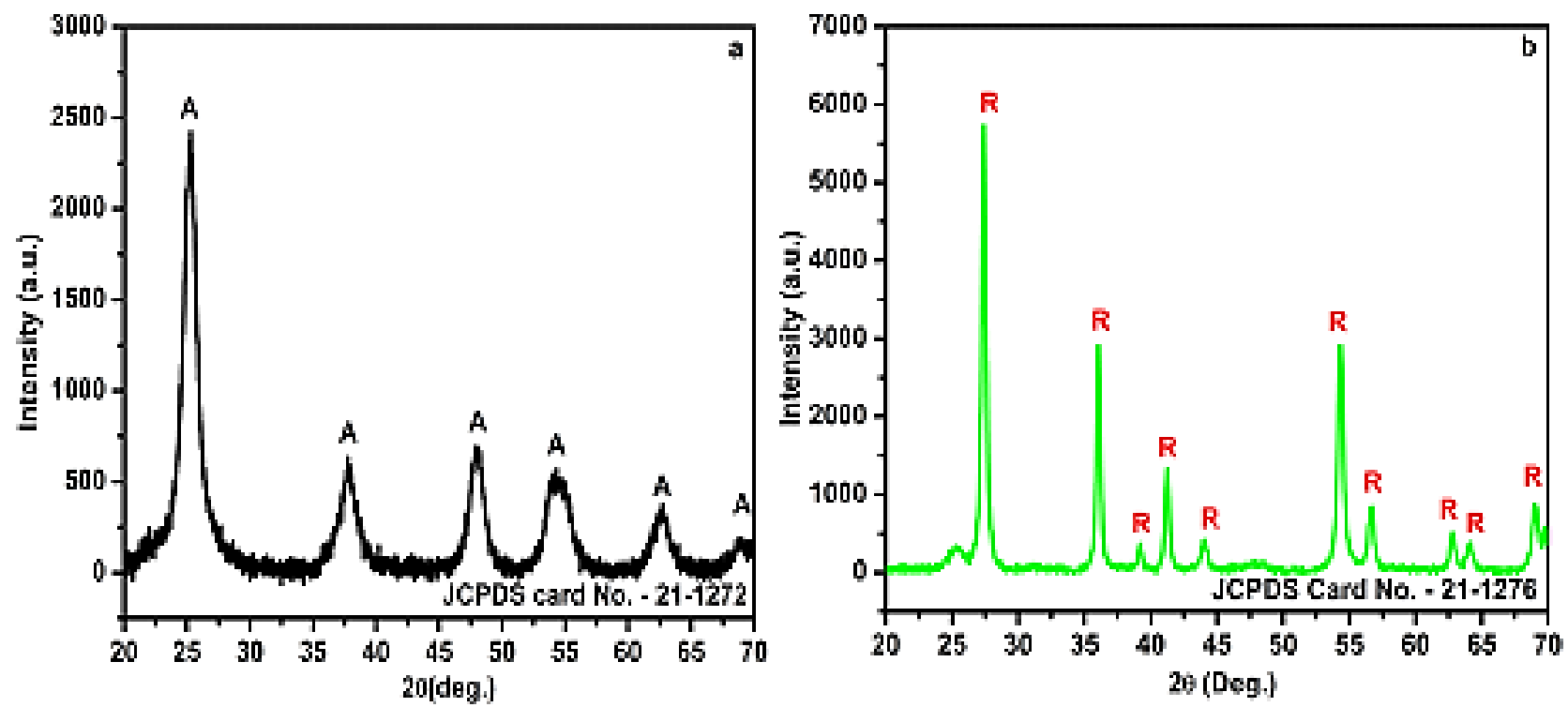

Fig. 5 Powder XRD pattern of as-synthesized $\mathrm{TiO}_{2} / \mathrm{SiO}_{2}$ nanocomposite calcined at a. $300{ }^{\circ} \mathrm{C}$ and b. $800{ }^{\circ} \mathrm{C}$ temperatures $(\mathrm{A}$-anatase and R-rutile).

cell volume as correlated to the reference pattern. On comparing our XRD result from the JCPDS Card No. 850335 for $\mathrm{SiO}_{2}$, JCPDS Card No. 21-1272 for $\mathrm{TiO}_{2}$ of the anatase phase, and JCPDS Card No. 21-1276 for $\mathrm{TiO}_{2}$ of rutile phase.

In the diffraction pattern, no clear peaks for $\mathrm{SiO}_{2}$ nanoparticles are observed because of their amorphous nature. The diffractogram shows the strongest $\mathrm{TiO}_{2}$ diffraction peaks in the anatase phase. The peaks of anatase $\mathrm{TiO}_{2}$ appeared at $2 \theta=25.3^{\circ}(101), 37.8^{\circ}(004), 48.0^{\circ}(200), 53.9^{\circ}(105), 62.7^{\circ}$ (204), $68.8^{\circ}(116)$ and $75.0^{\circ}(215)$. In XRD results, it can be clearly observed that the synthesized material has a tetragonal crystal structure with the lattice parameters: $a=3.785 \AA$ and $\mathrm{c}=9.513 \AA$. From Fig. 5(a), the $\mathrm{TiO}_{2} / \mathrm{SiO}_{2}$ nanocomposite calcinated at $300{ }^{\circ} \mathrm{C}$, and the anatase peaks are presented, indicating a high-quality crystalline material. However, the results show that the particles with regular shapes and smaller particle sizes are pronounced. At $300{ }^{\circ} \mathrm{C}$, the average crystallite size of the $\mathrm{TiO}_{2} / \mathrm{SiO}_{2}$ composite nanoparticle was $6.40 \mathrm{~nm}$ and the observed changes within the unit cell volume of the $\mathrm{TiO}_{2} / \mathrm{SiO}_{2}$ composite are $135.48 \AA^{3}$.

On increasing the calcination temperature up to $800{ }^{\circ} \mathrm{C}$, $\mathrm{TiO}_{2}$ powder transforms in the rutile phase confirmed by the diffraction peaks seen in Fig. 5(b). Rutile $\mathrm{TiO}_{2}$ appeared at $2 \theta=27.4^{\circ}(110), 36.0^{\circ}(101), 39.1^{\circ}$ (200), 54.3 ${ }^{\circ}(211), 56.6^{\circ}$ $(220), 64.5^{\circ}(310), 69.2^{\circ}(301), 70.3^{\circ}(112)$. Results from XRD analysis have shown that the synthesized material has a tetragonal crystal structure and has a primitive lattice with lattice parameters: $\mathrm{a}=4.5933 \AA$ and $\mathrm{c}=2.9592 \AA$. The average crystallite size of the $800{ }^{\circ} \mathrm{C}$ temperature sample $\mathrm{TiO}_{2} / \mathrm{SiO}_{2}$ nanocomposite was $21.42 \mathrm{~nm}$, and a change in the $\mathrm{TiO}_{2}$ unit cell volume was $62.72 \AA^{3}$. This indicates that the rutile nuclei tend to grow more than the anatase, and shows that with increasing the calcination temperature, the crystallite size increases. However, the intensity of the diffraction peaks ii increased as the calcination temperature is raised, which indicates an improvement in the material crystallinity. This result indicates that the $\mathrm{TiO}_{2} / \mathrm{SiO}_{2}$ nanocomposite calcined at $300{ }^{\circ} \mathrm{C}$ could effectively retard the growth of nanoparticles, clear crystallinity, and reduce the crystallite size.

FT-IR analysis was performed with $\mathrm{KBr}$ and fine powder mixed in order to identify the component composition and functional groups of unknown samples. FT-IR is a tool like the fingerprint of all organic compounds and some inorganic compounds, which cannot be the same for 2 different samples. FT-IR spectra were taken at room temperature within the spectral range between 600 to $4000 \mathrm{~cm}^{-1}$. The FT-IR spectrum of the $\mathrm{TiO}_{2} / \mathrm{SiO}_{2}$ nanocomposite sample is shown in Fig. 6. In the sample calcined at $300{ }^{\circ} \mathrm{C}$, the peaks at $3444 \mathrm{~cm}^{-1}-3182$ $\mathrm{cm}^{-1}$ and $1631 \mathrm{~cm}^{-1}$ show the bending vibration of $-\mathrm{OH}$. In the spectrum of $\mathrm{TiO}_{2}$, the peak at $671 \mathrm{~cm}^{-1}$ shows the stretching vibration of Ti-O and the peak at $1458 \mathrm{~cm}^{-1}$ shows the stretching vibrations of Ti-O-Ti.

The observed band at around $1219 \mathrm{~cm}^{-1}-1178 \mathrm{~cm}^{-1}$ can be assigned to the stretching and bending of the Si-O-Si bond. The strong bands at $1060 \mathrm{~cm}^{-1}$ are a duo to the stretching of $\mathrm{Si}-\mathrm{OH}$ and $\mathrm{Ti}-\mathrm{OH}$. The sample shows another weak band at around $950 \mathrm{~cm}^{-1}$. The Si-O species of Si-O-Ti or Si-O defect sites that are formed due to the inclusion of $\mathrm{Ti}^{4+}$ ions into $\mathrm{SiO}_{2}$ matrixes in four-fold coordination with $\mathrm{SiO}_{4}{ }^{4-}$ oxygen has been designed for stretching this band. ${ }^{[24]}$ The absorption peak at $766 \mathrm{~cm}^{-1}$ shows the bending vibrations of Ti-O-Si. On calcination, the $\mathrm{TiO}_{2} / \mathrm{SiO}_{2}$ sample at $300{ }^{\circ} \mathrm{C}$, other absorption bands are hindered. This result of FT-IR indicates that the stable $\mathrm{TiO}_{2} / \mathrm{SiO}_{2}$ composite nanoparticles were prepared by $\mathrm{TiO}_{2}$ with $\mathrm{SiO}_{2}$ nanoparticles and confirmed that the metal oxide bond of pure $\mathrm{TiO}_{2} / \mathrm{SiO}_{2}$ solid solution is present to give rise to anatase structure and suppresses the transformation from anatase to rutile of $\mathrm{TiO}_{2}$ and enhances the crystallinity in $\mathrm{SiO}_{2 \cdot}{ }^{[25]}$ 


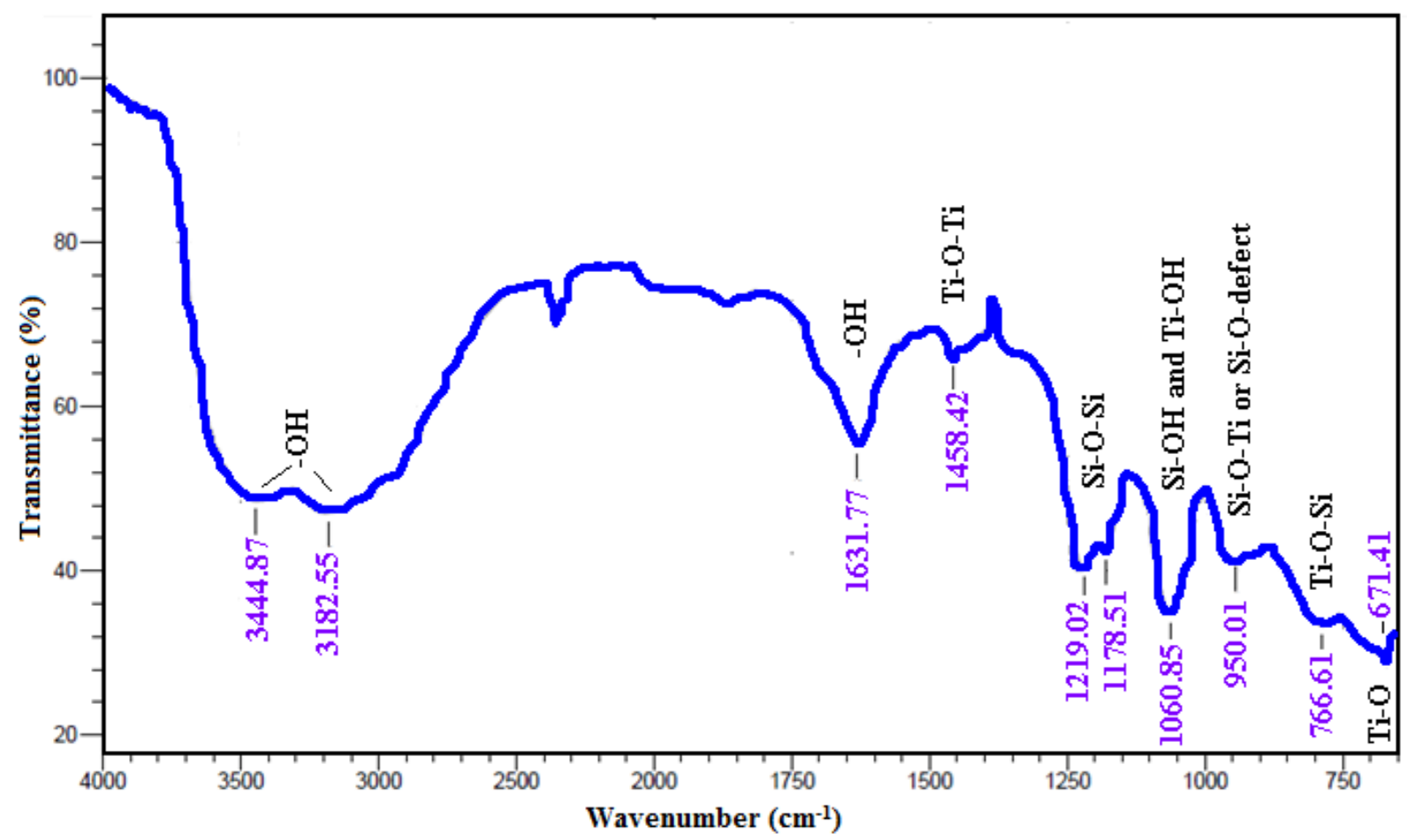

Fig. 6 FT-IR absorption spectra of $\mathrm{TiO}_{2} / \mathrm{SiO}_{2}$ nanocomposite calcined at $300{ }^{\circ} \mathrm{C}$ temperature.

The TEM was used to analyze the estimated particle size of the prepared samples of $\mathrm{TiO}_{2} / \mathrm{SiO}_{2}$ calcined at $300{ }^{\circ} \mathrm{C}$. The TEM micrographs in Fig. 7 show nearly spherical particles, which are highly uniformly dispersed and less aggregated. The mean particle sizes measured are $18.40 \mathrm{~nm}$. The main noticeable result is that the $\mathrm{TiO}_{2}$ particles are surrounded by $\mathrm{SiO}_{2}$ spheres of around $10-20 \mathrm{~nm}$ in size. This structure plays an essential role in the design and use of these highly efficient photocatalytic systems. The formation of the Ti-O-Si on the interface is also confirmed by FT-IR spectra by a visible peak at around $950 \mathrm{~cm}^{-1}$.

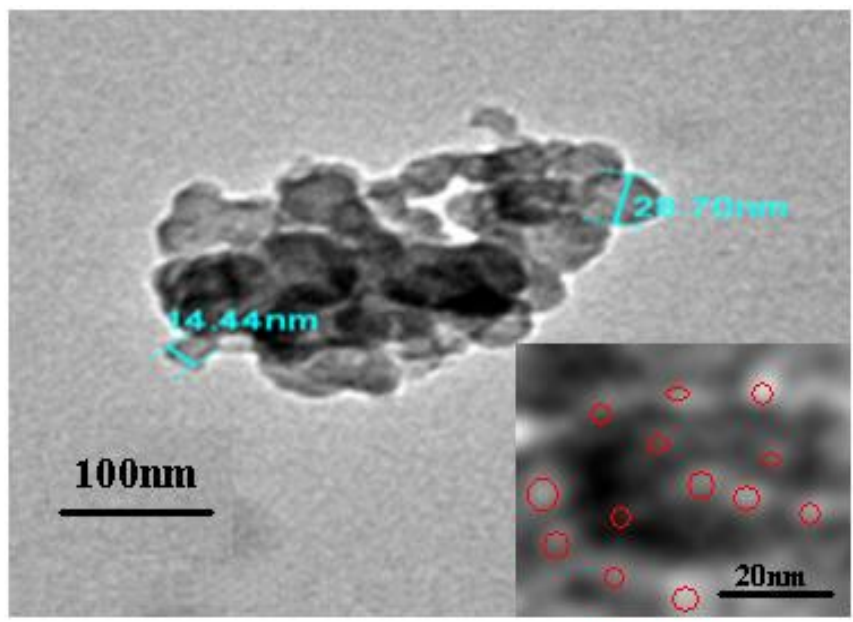

Fig. 7 TEM micrograph of $\mathrm{TiO}_{2} / \mathrm{SiO}_{2}$ nanocomposite calcined at $300{ }^{\circ} \mathrm{C}$. The core structure of $\mathrm{TiO}_{2}$ covered with particles of $\mathrm{SiO}_{2}$

UV-Visible characterization is done for observing the optical behavior of the synthesized material. The UV-visible absorption spectra of the $\mathrm{TiO}_{2} / \mathrm{SiO}_{2}$ nanocomposite synthesized via the sol-gel route calcined at different temperatures are shown in Fig. 8. The band gap energy $\left(E_{g}\right)$ was determined by Equation (4). ${ }^{[26]}$

$$
\mathrm{E}_{\mathrm{g}}=1239.8 / \lambda
$$

where $E_{g}$ is the band gap and $\lambda$ is the absorption edge of the spectrum.

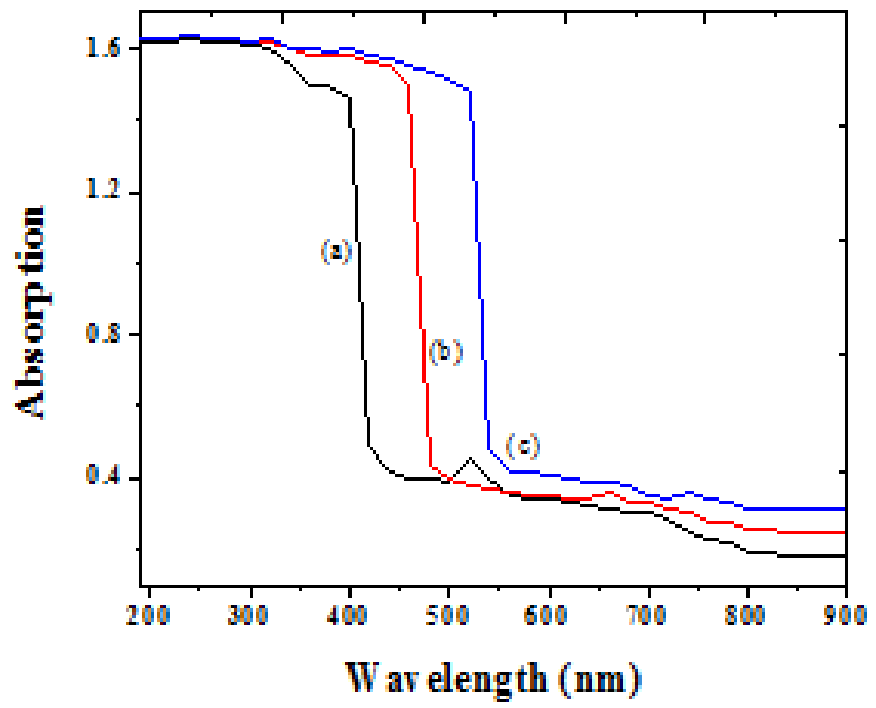

Fig. $8 \mathrm{UV}$-Vis absorption spectra of $\mathrm{TiO}_{2} / \mathrm{SiO}_{2}$ nanocomposite calcined at (a) $300{ }^{\circ} \mathrm{C}$, (b) $500{ }^{\circ} \mathrm{C}$ and (c) $800{ }^{\circ} \mathrm{C}$.

Fig. 8(a) shows that due to fine particles with a purity anatase phase display high nanoscale crystallinity in the substance. The absorption spectra of $\mathrm{TiO}_{2} / \mathrm{SiO}_{2}$ nanocomposite calcined at $300{ }^{\circ} \mathrm{C}$ can be attributed to a wavelength of $435 \mathrm{~nm}$ as the band gap is $2.85 \mathrm{eV}$ due to the presence of fine particle with pure anatase phase to show a high nano-crystallinity in the 
material. From Figs. $8(\mathrm{~b}$ and c), the synthesized nanocomposite sample calcined at $500{ }^{\circ} \mathrm{C}$ and $800{ }^{\circ} \mathrm{C}$, the absorption peaks, defined at $485.07 \mathrm{~nm}$ and $560.00 \mathrm{~nm}$, respectively, show a red shift in the samples.

The band gap of the $\mathrm{TiO}_{2} / \mathrm{SiO}_{2}$ composite sample calcined at $500{ }^{\circ} \mathrm{C}$ and $800{ }^{\circ} \mathrm{C}$ is $2.55 \mathrm{eV}$ and $2.21(\mathrm{eV})$, respectively. On calcination at $500{ }^{\circ} \mathrm{C}$ and $800{ }^{\circ} \mathrm{C}$, it shows good absorption in the visible region but an aggregation in the material (by SEM analysis). These UV-Vis absorption edges are similar, indicating good absorption in the visible region. ${ }^{[21]}$ It is denoted that the absorption in the UV region is decreased for $\mathrm{TiO}_{2} / \mathrm{SiO}_{2}$ sample due to the coverage of $\mathrm{SiO}_{2}$ on the $\mathrm{TiO}_{2}$ surface, which restrained the absorption of UV light. The coverage of $\mathrm{SiO}_{2}$ on $\mathrm{TiO}_{2}$ is well observed in the TEM micrograph of the sample.

The photoluminescence (PL) spectra of $\mathrm{TiO}_{2} / \mathrm{SiO}_{2}$ nanocomposite samples calcined at various temperatures were measured as shown in Fig. 9. This range of emission (270 to $700 \mathrm{~nm}$ ), which is excited by a particular wavelength gives certain wavelength peaks. The luminescence characteristics depend also on other crucial factors, including solvent, atmosphere materials from the start, etc. ${ }^{[27]}$ From Fig. 9(a), $\mathrm{TiO}_{2} / \mathrm{SiO}_{2}$ nanocomposite sample with more crystalline materials show a pure anatase phase calcined at $300^{\circ} \mathrm{C}$. The intensity of the PL spectrum is divided into sharp peaks. The result indicated that the formation of resolved multiple lines means that the structure of the positive ion in the spherical

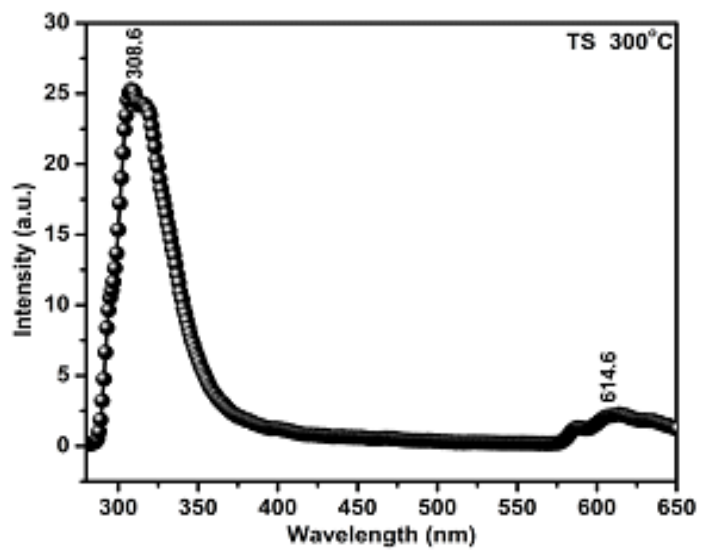

structure of $\mathrm{TiO}_{2} / \mathrm{SiO}_{2}$ was placed on the well-defined lattice site. Fig. 9(b and c) shows that the emission intensities with a large due to agglomerated lattice sites are calcined with $\mathrm{TiO}_{2} / \mathrm{SiO}_{2}$ samples at $500{ }^{\circ} \mathrm{C}$ and at $800{ }^{\circ} \mathrm{C}$. Emission peaks at $308.6 \mathrm{~nm}, 587 \mathrm{~nm}$, and $614.6 \mathrm{~nm}$ are shown in the PL sample spectra, $\mathrm{TiO}_{2} / \mathrm{SiO}_{2}$ at $300{ }^{\circ} \mathrm{C}, \mathrm{TiO}_{2} / \mathrm{SiO}_{2}$ at $500{ }^{\circ} \mathrm{C}$, and $\mathrm{TiO}_{2} / \mathrm{SiO}_{2}$ at $800{ }^{\circ} \mathrm{C}$. The peak shift towards the red wavelength may suggest that the particle size has grown. The lower PL intensity of PL shows that the rate of recombination decreases and therefore the higher photocatalytic activity decreases. ${ }^{[28]}$ The PL spectra of nanocomposite $\mathrm{TiO}_{2} / \mathrm{SiO}_{2}$ calcined with sharp peaks and lower intensity at $300{ }^{\circ} \mathrm{C}$ indicated that a decrease in recombination rate is expected, which results in higher photocatalytic activity.

\subsection{Photocatalytic properties of synthesized $\mathrm{TiO}_{2} / \mathrm{SiO}_{2}$} nanocomposite

Methylene blue (MB) and methyl orange (MO) were photodegraded using visible light and UV light irradiation, respectively. The photodegradation performance of $\mathrm{TiO}_{2} / \mathrm{SiO}_{2}$ nanocomposite samples produced and calcined at different temperatures for 120 minutes is shown in Fig. 10 and Fig. 11, respectively. After every 30 minutes up to 2 hours, the concentration of dye was measured based on their characteristic peak in the UV-vis spectra, and the degradation $\%$ was calculated using Equation (2). We plotted the degradation \% with respect to time for both dyes.
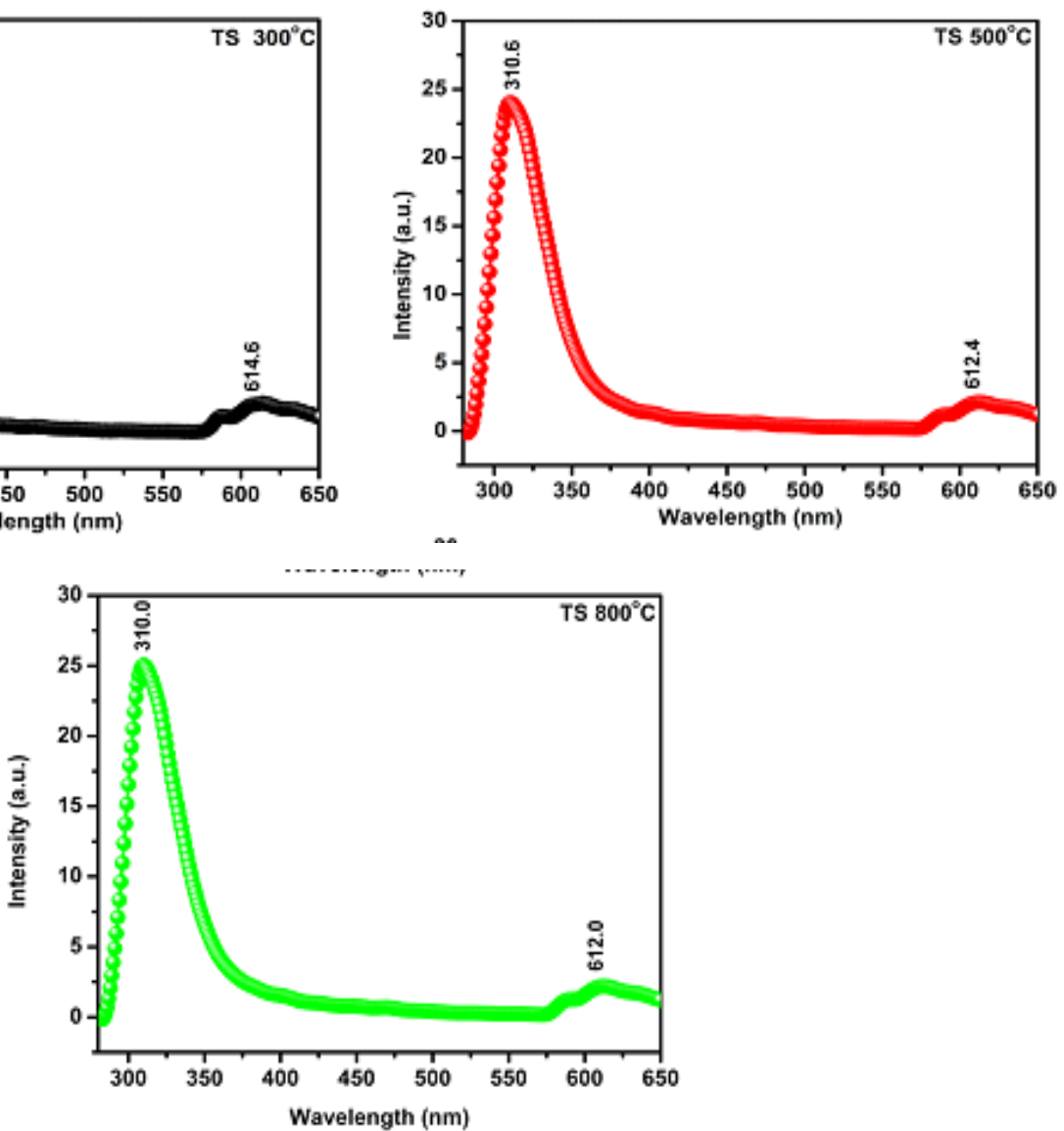

Fig. 9 Photoluminescence emission spectra of $\mathrm{TiO}_{2} / \mathrm{SiO}_{2}$ nanocomposite calcined at (a) $300{ }^{\circ} \mathrm{C}$, (b) $500{ }^{\circ} \mathrm{C}$ and (c) $800{ }^{\circ} \mathrm{C}$. 


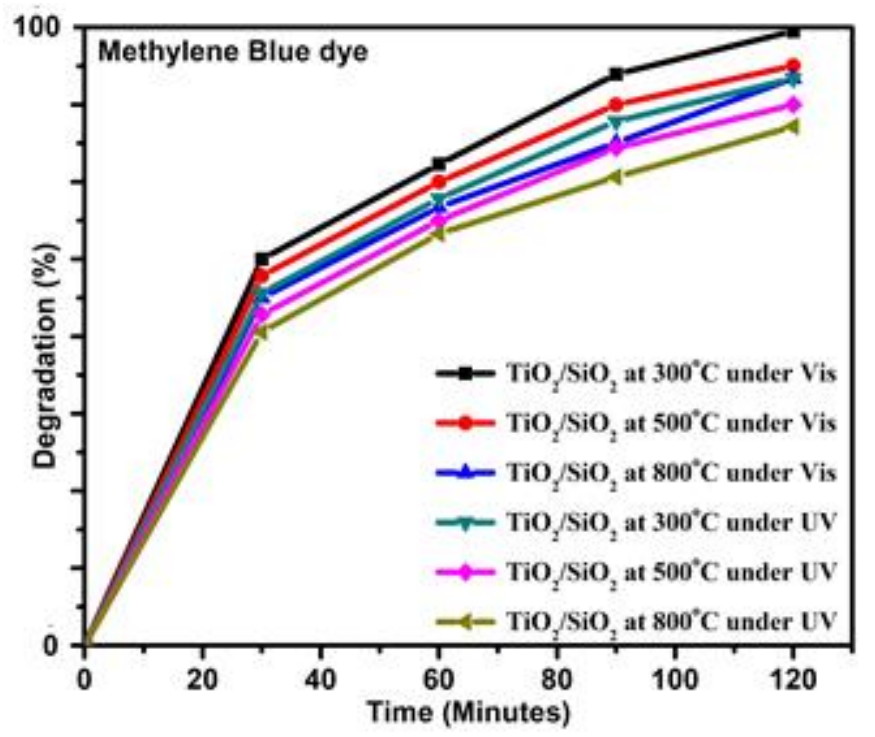

Fig. 10 Photodegradation performances of $\mathrm{MB}$ by $\mathrm{TiO}_{2} / \mathrm{SiO}_{2}$ sample calcined at (a) $300{ }^{\circ} \mathrm{C}$, (b) $500{ }^{\circ} \mathrm{C}$, and (c) $800{ }^{\circ} \mathrm{C}$ under $\mathrm{UV}$ and visible light irradiation for 120 minutes.

Figure 10 and Fig. 11 show that the sample $\mathrm{TiO}_{2} / \mathrm{SiO}_{2}$ calcined at $300{ }^{\circ} \mathrm{C}$ shows a higher activity in photodegradation because of its small crystallite size and high surface-to-volume ratio. The anatase phase of $\mathrm{TiO}_{2} / \mathrm{SiO}_{2}$ exhibits a smaller particle growth with a regular and homogeneous spherical shape, which is beneficial to the photodegradation rate. $\mathrm{SiO}_{2}$ particles effectively inhibit the particle growth in the crystalline $\mathrm{TiO}_{2}$ network, resulting in a more regular and uniform spherical in nature and a faster rate of degradation. $\mathrm{TiO}_{2} / \mathrm{SiO}_{2}$ exhibits a higher percentage of photodegradation due to a complete crystallization with anatase phase and smaller particle size and high specific surface area at $300{ }^{\circ} \mathrm{C}$, which were confirmed by TEM, XRD, and BET analysis. ${ }^{[29-31]}$

However, with the increase of calcination temperatures at $500{ }^{\circ} \mathrm{C}$ and $800{ }^{\circ} \mathrm{C}$, with pure rutile phase (from XRD data) with larger crystallite size, particle growth, and sintering rate, the photodegradation activity of three $\mathrm{TiO}_{2} / \mathrm{SiO}_{2}$ samples is clearly declined. The calcination sample of $300^{\circ} \mathrm{Chas}$ a higher photodegradation percentage in comparison with the catalytic performance of all three samples calcined at different temperatures due to complete crystallization with the smaller particle size and larger specific surface area. This is consistent with the fact that anatase, due to its high crystallinity, is more photocatalytically active than rutile.

The results show that, from Fig. 10 and Fig. 11, the photodegradation of $\mathrm{MB}$ and $\mathrm{MO}$ by $\mathrm{TiO}_{2} / \mathrm{SiO}_{2}$ sample calcined at different temperatures shows higher photodegradation performances under visible sources than UV sources. From Fig. 10, $\mathrm{TiO}_{2} / \mathrm{SiO}_{2}$ nanocomposite samples calcined at $300{ }^{\circ} \mathrm{C}$ show good photodegradation activity of MB under visible light. The degradation of dye by this sample is $90 \%$ in visible light and $80 \%$ in UV light. This is in good agreement with the results obtained from UV-vis absorption spectra and PL spectroscopy. Photodegradation of MO by
$\mathrm{TiO}_{2} / \mathrm{SiO}_{2}$ sample calcined at $300{ }^{\circ} \mathrm{C}$ displays a greater degradation under the visible irradiation as shown in Fig. 11.

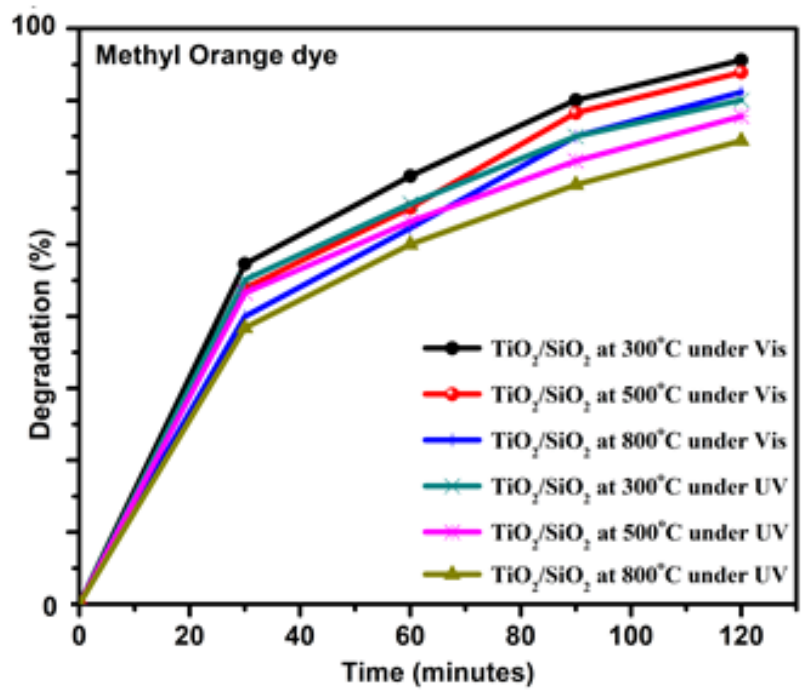

Fig. 11 Photodegradation performances of $\mathrm{MO}$ by $\mathrm{TiO}_{2} / \mathrm{SiO}_{2}$ sample calcined at $300{ }^{\circ} \mathrm{C}, 500{ }^{\circ} \mathrm{C}$, and $800{ }^{\circ} \mathrm{C}$ under UV and visible light irradiation for 120 minutes.

The degradation of this sample is $75 \%$ in visible light and $70 \%$ in UV light. From Fig. 12, one can see that the $\mathrm{TiO}_{2} / \mathrm{SiO}_{2}$ catalyst absorbs the solute more efficiently under visible irradiation, resulting in a significant increase in the rate of photocatalytic breakdown of $\mathrm{MB}$. In the visible region, the sample $\mathrm{TiO}_{2} / \mathrm{SiO}_{2}$ has a considerably wider spectrum, increasing the odds of light of the right wavelength striking the photocatalyst surface and activating it. ${ }^{[32]}$ Due to the lower absorption of the dye wavelength, the MB dye performs somewhat better than the MO dye in photodegradation when compared to the photodegradation performance of both dyes in all $\mathrm{TiO}_{2} / \mathrm{SiO}_{2}$ samples. The photodegradation of the $\mathrm{TiO}_{2} / \mathrm{SiO}_{2}$ catalyst continues to increase with continued irradiation, and no saturation is observed in the overall experiment. ${ }^{[33,34]}$

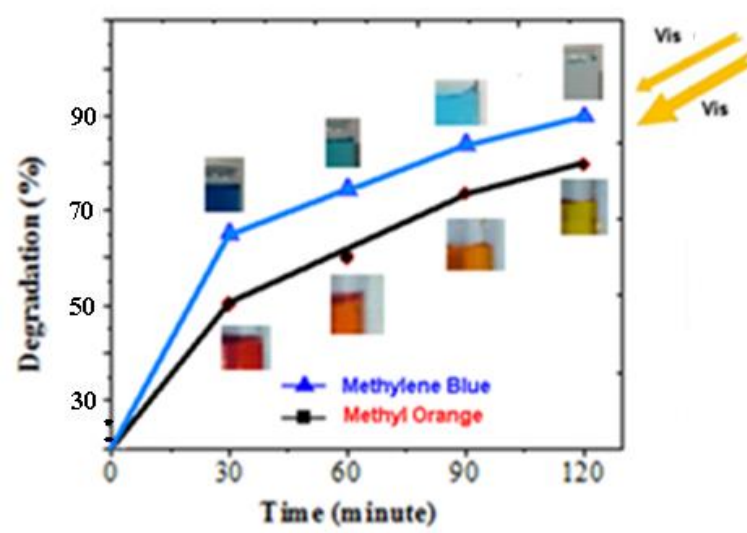

Fig. 12 Photodegradation performances of $\mathrm{MB}$ and $\mathrm{MO}$ using $\mathrm{TiO}_{2} / \mathrm{SiO}_{2}$ nanocomposite calcinated at $300{ }^{\circ} \mathrm{C}$ under the visible light source. 


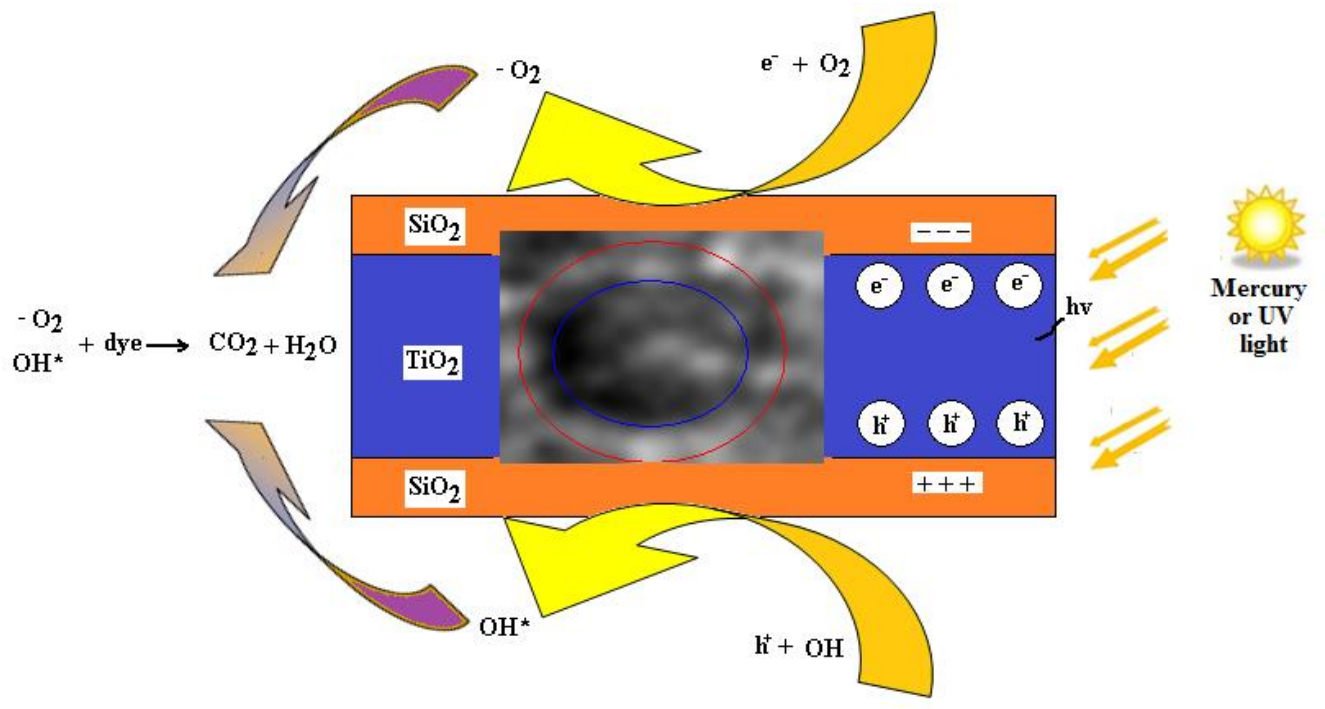

Fig. 13 Photodegradation mechanism of dye through $\mathrm{TiO}_{2} / \mathrm{SiO}_{2}$ nanocomposite.

The degradation performance of $\mathrm{TiO}_{2} / \mathrm{SiO}_{2}$ samples calcined at $300{ }^{\circ} \mathrm{C}$ has a slightly higher percentage for MB than MO. The result reveals that the photodegradation performance of $\mathrm{TiO}_{2} / \mathrm{SiO}_{2}$ calcined at $300{ }^{\circ} \mathrm{C}$ is better due to the large specific surface area, smaller particle size, anatase phase, and high crystallinity. ${ }^{[35,36]}$ The result indicated the best photodegradation performance of $\mathrm{MB}$ under the visible light source of a sample with $\mathrm{TiO}_{2} / \mathrm{SiO}_{2}$ calcined at $300{ }^{\circ} \mathrm{C}$. Fig. 13 explains well the photodegradation mechanism of dye $\mathrm{MB}$ and MO through $\mathrm{TiO}_{2} / \mathrm{SiO}_{2}$ nanocomposite under sunlight.

\section{Conclusions}

The $\mathrm{TiO}_{2} / \mathrm{SiO}_{2}$ nanocomposite was successfully synthesized via a sol-gel method. The characterization analyses confirmed the successful synthesis of $\mathrm{TiO}_{2} / \mathrm{SiO}_{2}$ nanocomposite. The $\mathrm{TiO}_{2} / \mathrm{SiO}_{2}$ calcined at $300{ }^{\circ} \mathrm{C}$ has a spherical shape. At higher calcination temperatures, the samples show agglomeration with a large particle size distribution. $\mathrm{TiO}_{2} / \mathrm{SiO}_{2}$ composite sample calcined at $300^{\circ} \mathrm{C}$ displayed a well-structured morphology with a macro-pore-free and uniform site. The XRD patterns consist of several strong diffraction peaks of $\mathrm{TiO}_{2}$ in the tetragonal crystal structure anatase phase. The increased diffraction peaks intensity of the $\mathrm{TiO}_{2} / \mathrm{SiO}_{2}$ confirms the improved crystallinity of the material. $\mathrm{TiO}_{2} / \mathrm{SiO}_{2}$ nanocomposite calcined at $800^{\circ} \mathrm{C}$ transforms into a rutile phase with a large crystallite size. FT-IR spectra justified the metal bond present as Ti-O-Ti, Si-O-Si, and Ti-O-Si. Due to the very fine anatase phase with a high crystallinity of the material, the absorption spectrum of $\mathrm{TiO}_{2} / \mathrm{SiO}_{2}$ nanocomposite can be calcined at $300{ }^{\circ} \mathrm{C}$ as a smaller band gap. On increasing the calcination temperature, the UV absorption peak shifts towards the higher wavelength. The absorption spectra of $\mathrm{TiO}_{2} / \mathrm{SiO}_{2}$ nanocomposite samples show an absorbance in the visible region, which was a good indication for the system being an effective photocatalyst in visible range or sunlight. The $\mathrm{PL}$ intensity of $\mathrm{TiO}_{2} / \mathrm{SiO}_{2}$ nanocomposite calcined at $300{ }^{\circ} \mathrm{C}$ has been split into many sharp peaks, which is due to good crystallization, thus reducing the recombination rate which causes a higher photocatalytic activity. While comparing, the degradation of both dyes, it is found that the same sample calcined at $300^{\circ} \mathrm{C}$ exhibits a better photodegradation for MB (80-85\%) than MO (70-75\%) under visible light irradiation within the duration of 2 hours.

\section{Acknowledgments}

The authors would like to thank Director MANIT, Bhopal (M.P) for all the help and support. The authors would also like to thank UGC-DAE-CSR Indore, India for providing XRD characterization. The support from HSADL, Bhopal is duly acknowledged for providing TEM analysis. The author would like to thank the R\&D Section, HEG, Bhopal (M.P) for providing BET surface area measurement.

\section{Conflict of Interest}

There is no conflict of interest.

\section{Supporting Information}

Not applicable.

\section{References}

[1] K. Hashimoto, H. Irie, A. Fujishima, Japanese Journal of Applied Physics, 2005, 44, 8269-8285, doi: 10.1143/jjap.44.8269. [2] A. Hagfeldt, M. Graetzel, Chemical Reviews, 1995, 95, 49-68, doi: 10.1021/cr00033a003.

[3] N. Singh, J. Bamne, K. M. Mishra, N. Singh, F. Z. Haque, Emerging Trends in Nanotechnology, 2021, 279-307, doi: 10.1007/978-981-15-9904-0_10.

[4] H. M. A. Javed, M. Sarfaraz, M. S. Mustafa, W. Que, Ateequr-Rehman, M. Awais, S. Hussain, A. A. Qureshi, M. Z. Iqbal, M.

A. Khan, Applied Nanoscience, 2020, 10, 2419-2427, doi: 10.1007/s13204-020-01430-x.

[5] S. Gupta, M. Tripathi, Open Chemistry, 2012, 10, 279-294, doi: 10.2478/s11532-011-0155-y. 
[6] F. Z. Haque, M. R. Parra, H. Siddiqui, N. Singh, N. Singh, P. Pandey, K. M. Mishra, Optics and Spectroscopy, 2016, 120, 408414, doi: 10.1134/s0030400x16030085.

[7] F. Akbal, Environmental Progress, 2005, 24, 317-322, doi: 10.1002/ep.10092.

[8] C. Rai, F.Z. Haque, Journal of Advanced Physics, 2015, 4, 15 18, doi: 10.1166/jap.2015.1168.

[9] R. Nandanwar, P. Singh, F. F. Syed, F. Z. Haque, Oriental Journal of Chemistry, 2014, 30, 1577-1584, doi: 10.13005/ojc/300417.

[10] P. Pandey, N. Singh, F. Z. Haque, Optik, 2013, 124, 1188 1191, doi: 10.1016/j.ijleo.2012.03.007.

[11] C. C. Wang, Z. Zhang, J. Y. Ying, Nanostructured Materials, 1997, 9, 583-586, doi:10.1016/S0965-9773(97)00130-X.

[12] R. Nandanwar, P. Singh, F. Z. Haque, Journal of Advanced Physics, 2014, 3, 141-145, doi: 10.1166/jap.2014.1123.

[13] G. Madras, B. J. McCoy, A. Navrotsky, Journal of the American Ceramic Society, 2007, 90, 250-255, doi: 10.1111/j.1551-2916.2006.01369.x.

[14] N. Singh, V. Pandey, N. Singh, M. M. Malik, F. Z. Haque, Journal of Optics, 2017, 46, 199-203, doi: 10.1007/s12596-0170404-3.

[15]_M. Yu, T. Yu, S. Chen, Z. Guo, I. Seok, 2020, ES Materials \& Manufacturing, 2020, 7, 64-69, doi: 10.30919/esmm5f712.

[16] F. Z. Haque, R. Nandanwar, P. Singh, Optik, 2017, 128, 191200, doi: 10.1016/j.ijleo.2016.10.025.

[17] C. J. Brinker, G. W. Scherer. Academic Press Inc, 2013, isbn; 0-12-134970-5.

[18] M. Cozzolino, M. D. Serio, R. Tesser, E. Santacesaria, Applied Catalysis A: General, 2007, 325, 256-262, doi: 10.1016/j.apcata.2007.02.032

[19] I. Kimura, T. Kase, Y. Taguchi, M, Tanaka, Materials Research Bulletin, 2003, 38, 585-597, doi: 10.1016/S00255408(03)00027-8.

[20] N. Singh, A. Umar, N. Singh, H. Fouad, O. Y. Alothman, F. Z. Haque, Materials Research Bulletin, 2018, 108, 266-274, doi: 10.1016/j.materresbull.2018.09.008.

[21] B.Wang, K. Wei, X. Mo, J. Hu, G. He, Y. Wang, W. Li, Q. He, ES Materials \& Manufacturing, 2019, 4, 51-57, doi: 10.30919 /esmm5f215.

[22] N. Singh, N. Singh, K. M. Mishra, F. Z. Haque, Journal of Advanced Physics, 2016, 5, 184-189, doi: 10.1166/jap.2016.1250. [23] J. Marugán, M.-J. López-Muñoz, W. Gernjak, S. Malato, Industrial \& Engineering Chemistry Research, 2006, 45, 89008908, doi: 10.1021/ie061033b.

[24] K. B. Tan, M. Vakili, B. A. Horri, P. E. Poh, A. Z. Abdullah, B. Salamatinia, Separation and Purification Technology, 2015, 150, 229-242, doi: 10.1016/j.seppur.2015.07.009.

[25] C. H. Nguyen, C. C. Fu, R. S. Juang, Journal of Cleaner Production, 2018, 202, 413-427, doi: 10.1016/j.jclepro.2018.08.110.

[26] X. Zhang, H. Zheng, Bulletin of Materials Science, 2008, 31, 787-790, doi: 10.1007/s12034-008-0125-y.

[27] A. A. Belhekar, S. V. Awate, R. Anand, Catalysis Communications, 2002, 3, 453-458, doi: 10.1016/s1566-
7367(02)00179-6.

[28] M. R. Parra, F. Z. Haque, Optik, 2014, 125, 4629-4632, doi: 10.1016/j.ijleo.2014.05.030.

[29] S. Liu, M. Wang, G. Liu, N. Wan, C. Ge, S. Hussain, H. Meng, M. Wang, G. Qiao, Applied Surface Science, 2021, 567, 150747, doi: 10.1016/j.apsusc.2021.150747.

[30] F. Z. Haque, N. Singh, P. Pandey, M. R. Parra, Optik, 2013, 124, 4167-4171, doi: 10.1016/j.ijleo.2012.12.052.

[31] S. Hu, A. Wang, X. Li, Y. Wang, H. Löwe, Chemistry - an Asian Journal, 2010, 5, 1171-1177, doi: 10.1002/asia.200900629. [32] S. Artkla, W. Kim, W. Choi, J. Wittayakun, Applied Catalysis B: Environmental, 2009, 91, 157-164, doi: 10.1016/j.apcatb.2009.05.019.

[33] H.-J. Kim, Y.-G. Shul, H. Han, Topics in Catalysis, 2005, 35, 287-293, doi: 10.1007/s11244-005-3836-y.

[34] C. Xu, R. Killmeyer, M. L. Gray, S. U. M. Khan, Applied Catalysis B: Environmental, 2006, 64, 312-317, doi: 10.1016/j.apcatb.2005.11.008.

[35]_R. B. Rajput, S. N. Jamble, R. B. Kale. Engineered Science, 2022, 17, 176-184 doi: 10.30919/es8d534.

[36] H. Yuan, H. Peng, J. Guan, Y. Liu, J. Dai, R. Su, Z. Guo, Y. Chen, Q. Hu, B. Yuan, H. Wu, D. Kilula, I. Seok, Engineered Science, 2020 9, 68-76, doi: 10.30919/es8d910.

\section{Author information}

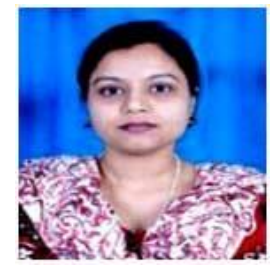

Dr. Ruchi Nandanwar awarded the Ph.D. doctoral degree in 2017 from the Barkatullah University, Bhopal (M.P), India and she has performed the experimental work in Optical Nanomaterials Lab in the Department of Physics, at Mulana Azad National Institute of Technology, Bhopal (M.P). Her research work is focused mainly on oxide nanomaterials for environmental applications. She has published 09 research papers. Research experiences- 10 years.

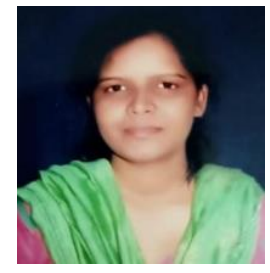

Dr. Jyoti Bamne awarded doctorate in 2021 from the Barkatullah University, Bhopal (M.P) India and the experimental work was carried out in Optical Nanomaterials Lab in the Department of Physics, at Mulana Azad National Institute of Technology, Bhopal (M.P). Her research work is focused mainly on oxide nanomaterials for environmental applications. She has published 07 research papers.

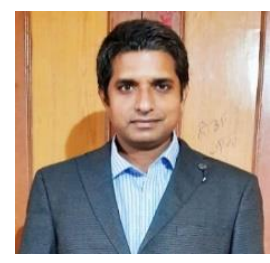

Dr. Nitu Singh awarded doctorate in 2019 from NIT, Bhopal. Madhya Pradesh, India. Qualified CSIR-NET (2011) in Physical Science. His area of interest for researches is in Nanoscience applications. He is member of peer review committee in Journal of Science and Technological Researches and Optical Engineering. Research experiences - 6 years. 


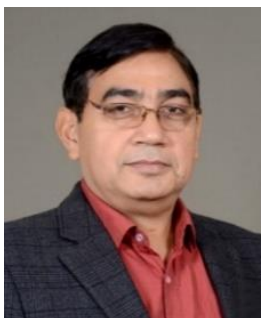

Dr. Praveen Kumar Sharma received his Ph.D. Degree in 1997 from School of Study in Physics, Vikram University, Ujjain India Presently he is working as Assistant Professor in University Institute of Technology, Barkatullah University, Bhopal since 1997. He is specialised in Plasma Instabilities used in ICF, Space and Astrophysics. Presently he is also working in field of Nanotechnology which includes growth, properties and their various technological applications. He has published 32 research papers in high index reputed Journals and 40 papers are presented in international \& national conferences. He has 26 years teaching experience in UG level and 20 years in PG level.

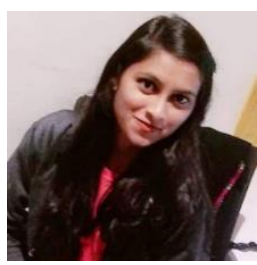

Ms. Kajol Taiwade Ph.D. Scholar from Optical Nanomaterials Lab in the Department of Physics, at Mulana Azad National Institute of Technology, Bhopal (M.P).

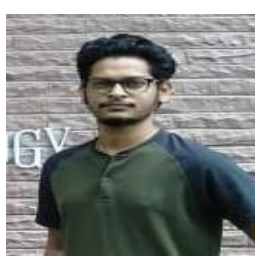

Mr. Vivek Chandel Ph.D. Scholar from Optical Nanotechnology Laboratory in Department of Physics, at Mulana Azad National Institute of Technology, Bhopal (M.P).

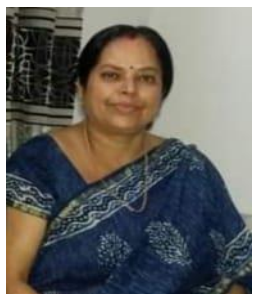

Dr. Purnima Singh awarded the Ph.D. degree in 2002 from the Department of Physics, Barkatullah University, Bhopal, India she is working as Professor with, at the Department of Physics, Sarojini Naido Govt. Girls (Autonomous) College, Bhopal (M. P.), India. Her present specialization is in the field of Materials Science. Teaching experience in $U G$ 26 years, $P G-22$ years, and Research experience- 24 years.

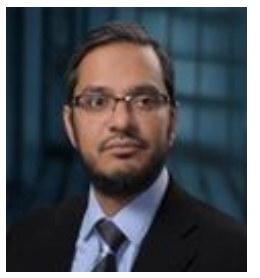

Prof. (Dr.) Ahmad Umar received his Ph.D. in semiconductor and chemical engineering from Jeonbuk National University, South Korea. He worked as a research scientist in Brain Korea 21, Centre for Future Energy Materials and Devices, Jeonbuk National University, South Korea, in 2007-2008. Afterwards, he joined the Department of Chemistry in Najran University, Najran, Saudi Arabia. He is a distinguished professor of chemistry and served as deputy director of the Promising Centre for Sensors and Electronic Devices (PCSED), Najran University, Najran, Saudi Arabia. Professor Ahmad Umar is specialized in 'semiconductor nanotechnology', which includes growth, properties and their various high technological applications, for instance, gas, chemicals and biosensors, optoelectronic and electronic devices, field effect transistors (FETs), nanostructure-based energy-harvesting devices, such as solar cells, Li-ion batteries, super-capacitors, semiconductor nanomaterial-based environmental remediation, and so on. $\mathrm{He}$ is also specialized in the modern analytical and spectroscopic techniques used for the characterizations and applications of semiconductor nanomaterials. He contributed to the world of science by editing world's first handbook series on Metal Oxide Nanostructures and Their Applications (5volume set, 3500 printed pages, www.aspbs.com/mona) and handbook series on Encyclopedia of Semiconductor Nanotechnology (7-volume set; www.aspbs.com/esn), both published by American Scientific Publishers (www.aspbs.com) He has published more than 600 research papers in reputed journal with h-index of 77 and i10-index of 394 with total citations of over 22000 (According to Google scholar).

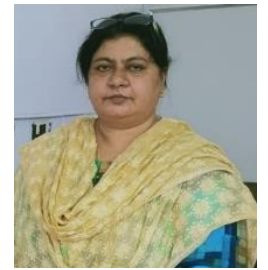

Dr Foiza Z. Haque has received her PhD degree in 2007 from the Department of Physics, DDU Gorakhpur University, Gorakhpur India. She has joined the Department of Physics at Mualana Azad National Institute of Technology, Bhopal (M.P) as Assistant professor in 2005 and presently she is Associate Professor and Head of the Department of Physics. She has vast experience of research and teaching in the field of nanotechnology preferably oxide nanomaterials for the various application like solar cell, gas sensor, photocatalysts and UV Shielding. She has supervised 10 PhD thesis and around 58 M.Tech. Nanotechnology thesis. She is the author of around 88 research papers in reputed SCI/Scopus indexed journals and 60 papers in conferences. Two books and 6 bookchapters are also published. She has awarded one patent in the area of optical gas sensing. She is a member of many prestigious society including INISEF-OWSD, Optical Society of America etc. She has travel USA and Saudi Arabia to deliver expert lectures and present papers in conferences.

Publisher's Note: Engineered Science Publisher remains neutral with regard to jurisdictional claims in published maps and institutional affiliations. 